Review Article

\title{
AN ASSESSMENT ON BUCCAL MUCOADHESIVE DRUG DELIVERY SYSTEM
}

\author{
LEELA LAKSHMI V. ${ }^{1}$, UMASHANKAR M. S. ${ }^{2 *}$, ALAGUSUNDARAM M. ${ }^{1}$
}

1Department of Pharmaceutics, Jagan's College of Pharmacy, Nellore, Andhra Pradesh, India, 2Department of Pharmaceutics, SRM College of Pharmacy, Chennai, India

Email: umashans@srmist.edu.in

Received: 27 Jul 2021, Revised and Accepted: 14 Sep 2021

\section{ABSTRACT}

Buccal drug delivery system (BDDS) has won a variety of exposure and traction as it possesses plenty of advantages and benefits as evaluate to different mucosal drug delivery systems. Buccal path for systemic drug delivery, the use of mucoadhesive polymers twill significantly increase the efficacy of many tablets, has been of outstanding interest over the previous couple of decades. This article affords a precise of BDDS mechanisms, consisting of a composition of the oral mucosa, delivery mechanism, numerous forms of BDDS, formulation, assessment and application of BDDS. Additionally, this text affords a precis over the patents, advertised products and destiny factors of BDDS. In this evaluation article, we've got tried to assemble the maximum significant reports (1988 to 2021) of formulation, assessment, application, patents of BDDS. This review will help pharmaceutical researchers to clarify the potential of BDDS to overcome the various existing drug delivery dispute like the efficiency of absorption, permeability and bioavailability of drugs.

Keywords: Buccal drug delivery, Mucoadhesive polymer, Formulation, Evaluation, Application, Patents

(C) 2021 The Authors. Published by Innovare Academic Sciences Pvt Ltd. This is an open access article under the CC BY license (https://creativecommons.org/licenses/by/4.0/] DOI: https://dx.doi.org/10.22159/ijap.2021v13i6.42760. Journal homepage: https://innovareacademics.in/journals/index.php/ijap

\section{INTRODUCTION}

Advancement and the progress made by the pharmaceutical industry that greatly contributed to treat the diseases, thus improving the quality of life [1]. With the passage of time researchers who are involved in the drug development industries focus on the alternative routes of administration of potentially capable pharmaceutical products and as well as to overcome defects that are associated with the oral route of administration. Though oral route is the most preferred route for the administration of major drugs, but it possesses certain drawbacks such as, the first pass metabolism in the liver, the local GI and enzymatic degradation inside the GI tracts [2].

In order to overcome the above mention drawbacks, one such strategy was used that is to deliver the drug through the alternative route such as Intranasal, Sublingual, Buccal, Pulmonary or Transdermal drug delivery systems [3]. Transmucosal method of drug transmission comprise of the mucosal lining of mouth, eye, vagina, rectum and nasal cavity which provides potential benefits over oral systemic drug delivery system. These features include the ability to bypass the first-pass metabolism, avoid the pre-elimination of the drug in the GI tack and dependence on the drug characters, it shows better enzymatic flora for the drug absorption [4].

Among the different mucosal pathways, the buccal mucosa has excellent accessibility, stretching of smooth muscle and relatively immobile mucosa; thus, this route of administration is suitable for controlled release of drugs from the dosage forms. By eliminating firstpass metabolism and enzymatic degradation owing to GI microbial flora, the oral mucosal drug delivery method is extensively applicable as a unique site for drug administration for immediate and controlled release action. Local and systemic action is provided through the oral mucosal medication delivery system. In addition, it exhibit great patient compliance as compare to other non-oral mucosal methods of drug administration. The Buccal drug delivery avoids acidolysis of the drug in GI system and bypasses the first-pass hepatic metabolism, which results the high bioavailability of the drug [5].

This article summarizes the advantage and disadvantages, application, evaluation, mechanism of the drug penetration, patents and marketed available pelletized drug delivery system. And also it will highlight the important terms and descriptions in the advantages, disadvantages, application, evaluation, mechanism of the drug penetration, patents and marketed available pelletized drug delivery system.

This review was conducted using Google search terms such as buccal mucoadhesive drug delivery system and articles relating to its formulation, evaluation, application and patents, which were collected from standard journals such as science direct, pubmed and scopus indexed journals.

\section{Physiological, anatomical features of the oral cavity}

The lips, hard palate (the bony front portion of the roof of the mouth), soft palate (the muscular back portion of the roof of the mouth), retromolar trigone (the area behind the wisdom teeth), front two-thirds of the tongue, gingiva (gums), buccal mucosa (the inner lining of the lips and cheeks), and floor of the mouth under the tongue are all parts of the oral cavity. In the following fig. 1 and table 1 , it show the composition of the oral cavity and its respective role in drug penetration.

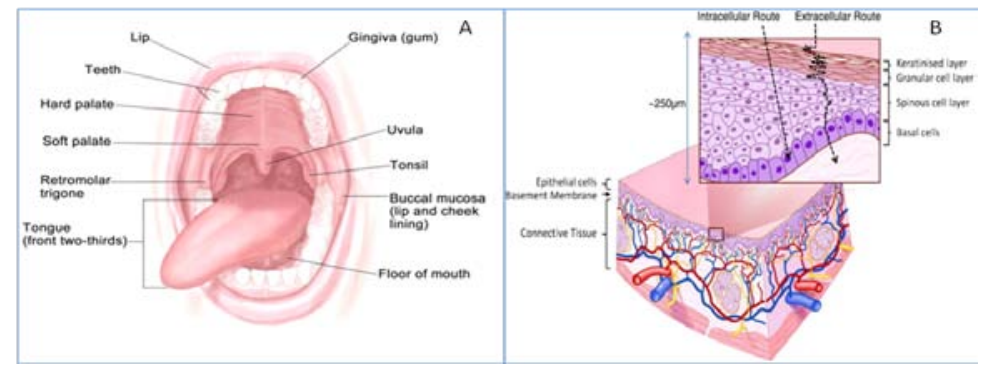

Fig. 1: (A) Anatomy of oral mucosa; (B) Transverse section of oral mucosa [2] 
Table 1: Composition of the oral cavity and mechanism of permeation enhancers

\begin{tabular}{|c|c|c|c|c|}
\hline $\begin{array}{l}\text { S. } \\
\text { No. }\end{array}$ & Composition of the oral cavity and its role & Thickness & $\begin{array}{l}\text { Drug permeation enhancement } \\
\text { mechanism }\end{array}$ & Reference \\
\hline 1. & $\begin{array}{l}\text { Epithelium Layer as shown in fig. } 1 \text { possesses two type } \\
\text { Non keratinized epithelium } \\
\text { It covers the soft palate, ventral surface of the tongue, } \\
\text { inner lip, floor of the mount and inner cheeks } \\
\text { Keratinized epithelium } \\
\text { It covers the gingiva, dorsal surface of the tongue and } \\
\text { hard palate. Role: Protective layer }\end{array}$ & $500-800 \mu \mathrm{m}$ & $\begin{array}{l}\text { The pores of the protective layer can be } \\
\text { enhanced by the addition of surfactant } \\
\text { (Anionic: Sodium lauryl sulfate Cationic: } \\
\text { Cetyl pyridinium chloride Nonionic: } \\
\text { Poloxamer, Brij, Span, Myrj, Tween) by } \\
\text { the agitation of intercellular Lipids and } \\
\text { its protein (keratin) domain structure }\end{array}$ & {$[2,3]$} \\
\hline 2. & $\begin{array}{l}\text { Basement Membrane } \\
\text { It forms a distinct layer between the epithelium and } \\
\text { connective layer } \\
\text { Role: Provides the adherence between the epithelium } \\
\text { and connective tissue and provide mechanical support } \\
\text { to the epithelium layer }\end{array}$ & $1-2 \mu \mathrm{m}$ & $\begin{array}{l}\text { Addition of positively charged polymers } \\
\text { like Chitosan, Cationic compounds like } \\
\text { Poly-L-arginine, L-lysine will show an } \\
\text { Ionic interaction with the negative charge } \\
\text { on the mucosal surface will paves the way } \\
\text { to the enhancement of drug through the } \\
\text { mucosa }\end{array}$ & {$[4,5]$} \\
\hline 3. & $\begin{array}{l}\text { Connective Tissue } \\
\text { It consists of lamina propria and submucosa layer. The } \\
\text { lamina propria consists of collagen fibers, supporting } \\
\text { layers, blood vessels and smooth muscles. } \\
\text { Role: Responsible for the blood supply to the oral cavity. } \\
\text { The Buccal artery like facial artery and infraorbital artery } \\
\text { are the predominant source of blood supply to cheek lining } \\
\text { in the Buccal cavity. Which will be responsible for } \\
\text { enhancement of drug penetration due to the predominant } \\
\text { source of blood supply }\end{array}$ & $150-500 \mu \mathrm{m}$ & $\begin{array}{l}\text { By adding a surfactant, Cyclodextrins, } \\
\text { Chelators, anionic and cationic } \\
\text { polymers may interfere with Ca+ions, } \\
\text { negative charge on the mucosal surface } \\
\text { will leads to enhancement of drug } \\
\text { permeability. }\end{array}$ & {$[6,7]$} \\
\hline 4. & $\begin{array}{l}\text { Mucus } \\
\text { Gel like secretion which was translucent and } \\
\text { continuous; } \\
\text { Composition } \\
\text { - Water insoluble glycoprotein(Mucin): } 1-5 \% \\
\text { - Water: } 95-99 \% \\
\text { - Proteins, enzymes, electrolytes and nucleic acids. } \\
\text { Role: It is a visco-elastic hydrogel which act as a } \\
\text { protective layer to the cell below. }\end{array}$ & $\begin{array}{l}\text { - Buccal } \\
\text { (Nonkeratinized)-500- } \\
600 \mu \mathrm{m} \text { with } 2.40 \\
\mathrm{ml} / \mathrm{min} / \mathrm{cm}^{2} \\
\text { - Sublingual } \\
\text { (Nonkeratinized)-100- } \\
200 \mu \mathrm{m} \text { with } 0.97 \\
\mathrm{ml} / \mathrm{min} / \mathrm{cm}^{2} \\
\text { - Gingival } \\
\text { (keratinized)-200 } \mu \mathrm{m} \\
\text { with } 1.47 \mathrm{ml} / \mathrm{min} / \mathrm{cm}^{2} \\
\text { - Palatal } \\
\text { (Keratinized)-250 } \mu \mathrm{m} \\
\text { with } 0.89 \mathrm{ml} / \mathrm{min} / \mathrm{cm}^{2}\end{array}$ & $\begin{array}{l}\text { By adding anionic and cationic surfactant, } \\
\text { bile salts (Sodium glycocholate, Sodium } \\
\text { tauro deoxycholate, Sodium tauro } \\
\text { cholate), Fatty acids (Oleic acid, Caprylic } \\
\text { acid, Lauric acid), Cyclodextrin, Chelator } \\
\text { (EDTA, Citric acid, Sodium salicylate, } \\
\text { Methoxy salicylates) } \\
\text { will either increase the fluidity of } \\
\text { phospholipid domains or agitate the } \\
\text { intercellular Lipids and its } \\
\text { protein(keratin) domain structure }\end{array}$ & {$[8,9]$} \\
\hline 5 & $\begin{array}{l}\text { Saliva } \\
\text { Role: Protective fluid, Source of mineralization for the } \\
\text { tooth enamel, Hydrate the oral drug delivery system }\end{array}$ & $\begin{array}{l}\text { Viscosity }-1.05 \mathrm{cP} \text { and } \\
1.29 \mathrm{cP} \text {, respectively }\end{array}$ & $\begin{array}{l}\text { Drug Permeation enhancement } \\
\text { mechanism: } \\
\text { Will either increase the fluidity of } \\
\text { phospholipid domains by adding bile } \\
\text { salt, fatty acids to the BDDS }\end{array}$ & {$[10,11]$} \\
\hline
\end{tabular}

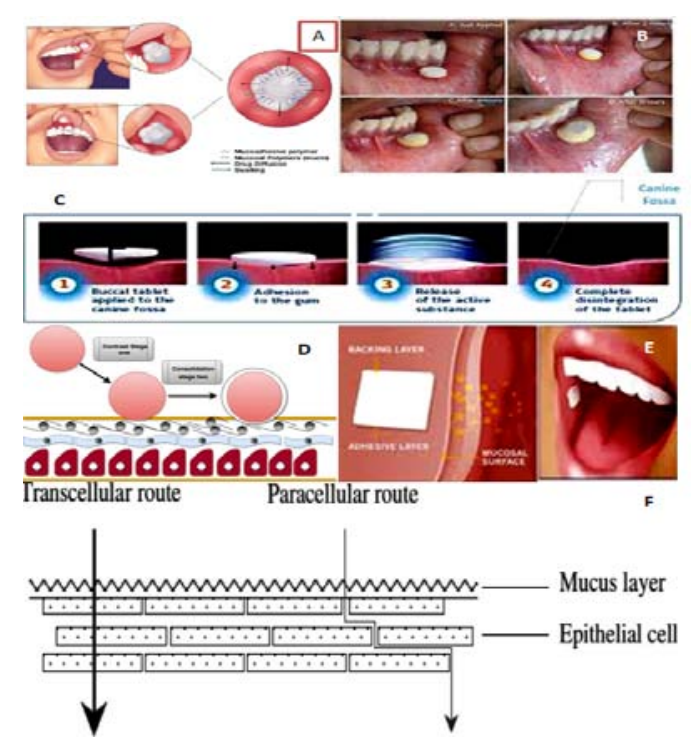

Fig. 2: (A) Buccal mucoadhesive tablet [5]; (B) Administration sites of buccal mucoadhesive tablets [6]; (C) Schematic representation of bioadhesion mechanism [8]; Buccal mucoadhesive films [9]; (D) Contact of BDDS to buccal mucosa [8]; (E) Buccal patch [9]; (F) Scheme of route of permeation from BDDS through buccal mucosa [3] 


\section{Transport mechanism}

Drug transport mechanism through the Buccal drug delivery is carried out by two mechanisms i.e. transcellular (intracellular) and paracellular (intercellular) as shown in fig. 2 (F). Paracellular route of permeation of the drug across the buccal epithelium is carried out through the passive diffusion. It is the most common route of transportation of various drug especially for the hydrophilic drugs i.e. protein or peptide which undergoes rapid dissolution in the aqueous fluid present in the intercellular spaces. For example caffeine is the drug which undergoes absorption via paracellular route and more often used as a marker for the paracellular absorption [9]. Whereas in case of trancellular pathway drug is penetrated through the cells i.e. by transferring the drug through the lipodial barrier i.e. cell membrane followed by the hydrophilic content of the series cell in order to reach the cytoplasmic content of the next cell. Example of the drug that penetrates via transcellular route of permeation is fentanyl [10]. Certain drugs may penetrate by using both the pathways which is possible only when the drug exhibit proper hydrophilic and lipophilic balance with a slight predominance of hydrophilic property. These drugs undergoes faster penetration, apart from these pathways alternative pathway like carrier mediated transport also play an major role for the penetration of the certain drugs across the membrane [11]. The major factors that influencing the penetration and bioavailability of the drug through the Buccal drug delivery includes permeability and thickness of the epithelium, blood supply, metabolic activity, saliva and mucous, species difference and route of mechanism [12].

\section{Novel buccal dosage formulations}

Table 2: Novel buccal dosage formulations

\begin{tabular}{|c|c|c|c|c|}
\hline S. No. & Dosage form & Description & Example & Reference \\
\hline 1. & $\begin{array}{l}\text { Buccal mucoadhesive } \\
\text { tablets as shown in fig. } \\
2(\mathrm{~A}, \mathrm{~B})\end{array}$ & $\begin{array}{l}\text { - Dry dosage form } \\
\text { - Must be moistened before use prior coming in contact with the } \\
\text { Buccal mucosa }\end{array}$ & $\begin{array}{l}\text { Double layer } \\
\text { tablet }\end{array}$ & {$[13,14]$} \\
\hline 2. & $\begin{array}{l}\text { Buccal patches as shown in } \\
\text { fig. } 2(\mathrm{E}) \\
\text { It is of two types } \\
\text { - Reservoir type } \\
\text { - Matrix type }\end{array}$ & $\begin{array}{l}\text { - Consists of two laminates with adhesive polymer(aqueous form) } \\
\text { which is glued over the backing sheet } \\
\text { - When it comes in contact with the mucosal membrane results in } \\
\text { the formation of the mucoadhesive bond between the adhesive } \\
\text { polymer and the mucosal polymer which is known as bioadhesion. } \\
\text { - Mechanism of bioadhesion can be explained by theories of } \\
\text { bioadhesion which include electronic, adsorption, wetting, diffusion } \\
\text { and fracture theory. } \\
\text { - Formation of mucoadhesive bond is carried out by three major } \\
\text { steps as shown in fig. } 2 \\
\text { 1. Wetting and swelling of polymer (contact stage). } \\
\text { 2. Interpenetration between the adhesive polymer and mucosal } \\
\text { membrane (mucin). } \\
\text { 3. Chemical bond formation (consolidation stage). }\end{array}$ & Zilactin & {$[15,16]$} \\
\hline 3. & $\begin{array}{l}\text { Semisolid dosage } \\
\text { form(ointments and gel) }\end{array}$ & $\begin{array}{l}\text { - Less patient compliance } \\
\text { - Exhibit localized action which is limited to oral cavity }\end{array}$ & Orabase & [17] \\
\hline 4. & Powders & - It increase the residence time of the drug in oral mucosa & $\begin{array}{l}\text { Hydroxypropyl } \\
\text { cellulose and } \\
\text { beclomethasone } \\
\text { combination }\end{array}$ & {$[18,19]$} \\
\hline 5. & Sprays & $\begin{array}{l}\text { It is made up of Mucoadhesive suspension, especially used through } \\
\text { nasal route }\end{array}$ & - & [17-19] \\
\hline
\end{tabular}

\section{Advantages and disadvantages of Buccal drug delivery system}

Table 3: Advantages and Disadvantages of the buccal drug delivery system

\begin{tabular}{|c|c|c|}
\hline Advantages & Disadvantages & Reference \\
\hline $\begin{array}{l}\text { - In contrast to the other mucosal tissues, the buccal mucosa is relatively permeable and has a good } \\
\text { blood supply. } \\
\text { - Bypass first pass metabolism } \\
\text { - Exhibits localized therapy } \\
\text { - Many medications would work better because they have a longer contact time with the mucosa. } \\
\text { - Patient acceptance is high as compared to other non-oral drug delivery methods. } \\
\text { - Lower administration frequency may result from increased residence time combined with } \\
\text { controlled API release. } \\
\text { - } \quad \text { API localization at the disease site can also result in substantial cost savings and a reduction in } \\
\text { dose-related side effects. } \\
\text { - The formulation stays longer at the delivery site as a result of adhesion and personal touch, } \\
\text { improving API bioavailability while using lower API concentrations for disease care. } \\
\text { - Buccal drug delivery removes the harsh environmental conditions that occur in oral drug delivery. } \\
\text { - It is a passive drug absorption mechanism that does not need any activation. } \\
\text { - In comparison to rectal or transdermal pathways, the presence of saliva guarantees a } \\
\text { comparatively large volume of water for drug dissolution. } \\
\text { - Provides a various different ways to administer hormones, narcotic analgesics, steroids, enzymes, } \\
\text { cardiovascular agents, and other medications. } \\
\text { - It allows for localized tissue permeability alteration, protease inhibition, and immunogenic } \\
\text { response reduction. As a result, therapeutic agents such as peptides, proteins, and ionized species } \\
\text { can be easily administered. }\end{array}$ & $\begin{array}{l}\text { - The total surface area of } \\
\text { the oral cavity membranes } \\
\text { usable for drug absorption is } \\
170 \mathrm{~cm}^{2} \text {, with non- } \\
\text { keratinized tissues, such as } \\
\text { the buccal membrane, } \\
\text { accounting for } 50 \mathrm{~cm}^{2} \text {. } \\
\text { - The mucosa's barrier } \\
\text { properties. } \\
\text { - The medication is diluted } \\
\text { as a result of the continuous } \\
\text { secretion of saliva (0.5-2 } \\
\text { l/day). } \\
\text { - The risk of choking if the } \\
\text { delivery system is swallowed } \\
\text { involuntarily is a concern. } \\
\text { - Swallowing saliva may } \\
\text { result in the loss of dissolved } \\
\text { or suspended drugs, as well } \\
\text { as the inadvertent removal of } \\
\text { the dosage type. }\end{array}$ & [16-20] \\
\hline
\end{tabular}


Table 4: Types of excipients and their role in the buccal drug delivery system

\begin{tabular}{|c|c|c|c|c|}
\hline $\begin{array}{l}\text { S. } \\
\text { No. }\end{array}$ & Excipient & Role & Example & Reference \\
\hline 1. & $\begin{array}{l}\text { Mucoadhesive } \\
\text { polymer }\end{array}$ & $\begin{array}{l}\text { Mucoadhesives are synthetic or natural } \\
\text { polymers that bind with the mucus layer } \\
\text { that coats the mucosal epithelial surface } \\
\text { and the major molecules that make up } \\
\text { mucus. } \\
\text { - It is the main excipients for adhesion by } \\
\text { attracting water, swells and adheres to the } \\
\text { mucous through forming a channel by } \\
\text { linking to mucin polymer } \\
\text { - They bind with mucin with help of H- } \\
\text { bonding group, hydrophilic group }\end{array}$ & $\begin{array}{l}\text { Semi synthetic/Natural polymer: } \\
\text { Agarose, gelatin, Hyaluronic acid, pectin and cellulose } \\
\text { derivatives. } \\
\text { Synthetic polymer: } \\
\text { Poly(acrylic acid)-based polymers } \\
\text { i.e. poly(acrylic acid-co-thylhexylacrylate), poly(methacrylate) } \\
\text { Water soluble polymer: } \\
\text { PAA,Sodium CMC,Sodiumalginate } \\
\text { Water insoluble polymer: } \\
\text { Chitosan (soluble in dilute aqueous acids), EC, PC } \\
\text { Cationic polymer: } \\
\text { Chitosan, Dimethylaminoethyl (DEAE)-dextran, trimethylated } \\
\text { chitosan } \\
\text { Non ionic polymer: } \\
\text { poly(ethylene oxide), PVA, PVP, scleroglucan } \\
\text { Anionic polymer: } \\
\text { Chitosan-EDTA, CP, CMC, pectin, PAA, PC, sodium alginate, } \\
\text { sodium CMC, xanthan gum }\end{array}$ & [21-23] \\
\hline 2. & $\begin{array}{l}\text { Permeation } \\
\text { enhancer }\end{array}$ & $\begin{array}{l}\text { Permeation enhancer }(<1 \%) \text { enhances the } \\
\text { permeation ability of the drug through the } \\
\text { epithelium membrane. The permeation } \\
\text { enhancer mechanism depends upon the } \\
\text { fick's first law of diffusion. } \\
\text { Its mechanism is as follows: } \\
\text { - Increasing fluidity and integrity of cell } \\
\text { membranes } \\
\text { - Extracting inter and intracellular lipids } \\
\text { - Altering cellular proteins } \\
\text { - Varying mucus rheology } \\
\text { - Enhancing thermodynamic activity of } \\
\text { drugs } \\
\text { - Decreasing surface tension }\end{array}$ & $\begin{array}{l}\text { Surfactant: } \\
\text { Ionic: Dioctyl Sodium sulfosuccinate, Polyoxyethylene-20- } \\
\text { cetyl ether } \\
\text { Nonionic: Nonylphenoxypolyoxyethylene(NP-POE)(nonionic), } \\
\text { Polyoxyethylene-9-lauryl ether (PLE) (nonionic) } \\
\text { Fatty acids and derivatives: } \\
\text { Acylcarnitine, Oleic acid, Caprylic acid, Mono(di)glycerides } \\
\text { and Lauric acid } \\
\text { Chelating agents: } \\
\text { EDTA,Citric acid and Salicylates } \\
\text { Polyols: Propylene glycol and Polyethylene glycol } \\
\text { Bile salts and derivatives: } \\
\text { Sodium deoxycholate), Sodium glycodihydrofusidate and } \\
\text { Sodium deoxycholate } \\
\text { Sulfoxides: Dimethyl sulfoxide(DMSO) } \\
\text { Others (non-surfactants): } \\
\text { Urea and derivative Azone(1-dodecylazacycloheptan-2-one) } \\
\text { (laurocapram) and cholines }\end{array}$ & [24-26] \\
\hline 3. & $\begin{array}{l}\text { Enzyme } \\
\text { inhibitor }\end{array}$ & $\begin{array}{l}\text { Enzyme inhibitors are used in the } \\
\text { formulation of BDDS in order to enchance } \\
\text { the drug absorption by decrease the affect } \\
\text { of the enzyme over the drug by altering the } \\
\text { structural configuration of enzyme and in } \\
\text { order to make the drug less susceptible } \\
\text { towards the enzyme degradation. }\end{array}$ & $\begin{array}{l}\text { Aprotinin, bestatin, puromycin, bile salts stabilize and } \\
\text { polyacrylic acid. }\end{array}$ & [27-29] \\
\hline
\end{tabular}

Manufacturing methods of the buccal tablets $[6,10,26]$

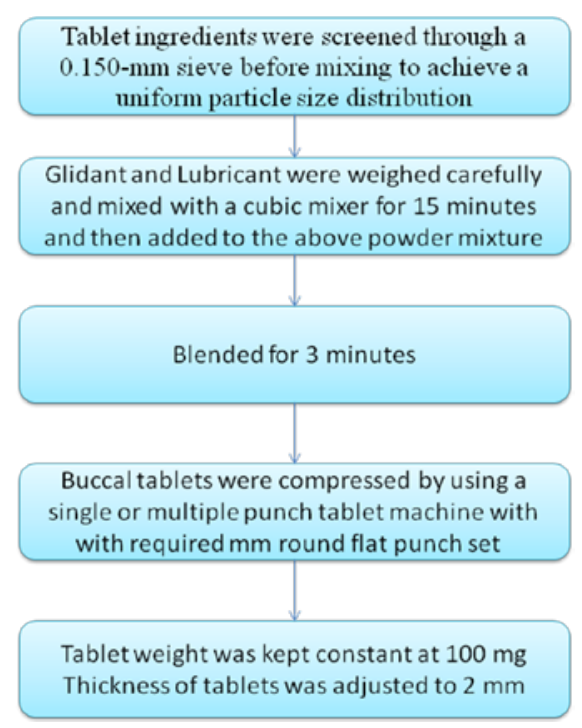


Table 5: Evaluation parameters of BDDS

\begin{tabular}{|c|c|c|c|c|c|}
\hline S. No. & Evaluation parameter & $\begin{array}{l}\text { Type of buccal dosage } \\
\text { form }\end{array}$ & Method used & Instrument & Reference \\
\hline 1. & Surface $\mathrm{pH}$ & Patch, Tablets Films & Visual colour change & pH meter & {$[32-35]$} \\
\hline 2. & Morphology & Tablets, Patches Films & Microscopy & $\begin{array}{l}\text { Scanning Electron } \\
\text { Microscopy (SEM) }\end{array}$ & [36-39] \\
\hline 3. & Swelling index & $\begin{array}{l}\text { Patches, Films Tablets, } \\
\text { Wafers }\end{array}$ & $\begin{array}{l}\text { Swelling of patch and tablet in } \\
\text { pH } 6.4 \text { phosphate buffer }\end{array}$ & Agar gel plates & {$[39-43]$} \\
\hline 4. & Folding endurance & Patches, Films & Repeated folding in same point & Manually folded & {$[43-45]$} \\
\hline 5. & Drug compatibility & $\begin{array}{l}\text { Patches, Films Tablets } \\
\text { Wafers }\end{array}$ & $\begin{array}{l}\text { Thermal analysis, } \\
\text { Spectral analysis }\end{array}$ & FTIR, DSC, XRD & {$[46-48]$} \\
\hline 6. & Thickness & $\begin{array}{l}\text { Patches, Films } \\
\text { Tablets, Wafers }\end{array}$ & Standard deviation & $\begin{array}{l}\text { Vernier calipers, Screw } \\
\text { guaze, Electronic digital } \\
\text { micrometer }\end{array}$ & {$[49-51]$} \\
\hline 7. & Mucoadhesive strength & Patches, Films Tablets & Tensile strength & Texture analyzer & {$[42,58,62]$} \\
\hline 8. & $\begin{array}{l}\text { Water absorption capacity } \\
\text { test }\end{array}$ & Patches Films & Agar plate technique & Desiccators & {$[52-54]$} \\
\hline 9. & Invitro drug release & $\begin{array}{l}\text { Tablets, Patches, Films } \\
\text { Microspheres }\end{array}$ & $\begin{array}{l}\text { Beaker method; Dissolution } \\
\text { method; Rotating paddle } \\
\text { method }\end{array}$ & $\begin{array}{l}\text { Kesary chein cell; } \\
\text { Franz diffusion cell }\end{array}$ & {$[55-58]$} \\
\hline 10. & Mechanical properties & $\begin{array}{l}\text { Patches, Films } \\
\text { Buccal hydrogels }\end{array}$ & Wilhelmy plate technique & $\begin{array}{l}\text { Microprocessor Modified } \\
\text { tensile strength tester }\end{array}$ & {$[59-62]$} \\
\hline 11. & Residence time & Patches Films & Disintegration & Modified disintegrator & {$[63,64]$} \\
\hline 12. & Palatability test & Patches Films & Grading of taste & E-taste meter & [65-68] \\
\hline 13. & Flatness & Patches Films & Percent constriction & Vernier calipers & {$[69,70]$} \\
\hline 14. & Drug content & Tablets, Patches Films & Titration & $\begin{array}{l}\text { RP-HPLC method, UV } \\
\text { spectrophotometer }\end{array}$ & {$[71-74]$} \\
\hline 15. & Hardness & Tablets Wafers & Crushing force & Monsanto hardness tester & {$[75-78]$} \\
\hline 16. & Friability & Tablets & Weighing & Roche friabilator & [79-83] \\
\hline 17. & Contact angle & Films & Wetting & Optical tensiometer & {$[72,84-86]$} \\
\hline 18. & Transparency & Films & Transmittance & UV spectrophotometer & [87-89] \\
\hline 19. & $\begin{array}{l}\text { Water vapour } \\
\text { transmission rate }\end{array}$ & Patches Films & Dressing method & Ovens & {$[90,91]$} \\
\hline 20. & Drug entrapment & Patches, Films, Microspheres & Assay & UV spectrophotometer & {$[82,91]$,} \\
\hline 21. & Bio-adhesion & Patches Films & $\begin{array}{l}\text { Colloidal gold staining method } \\
\text { Florescence probe method }\end{array}$ & Dissolution cells & {$[92,93]$} \\
\hline 22. & Percentage moisture loss & Patches Films & Gravimetry method & Desicator & {$[94,95]$} \\
\hline 23. & $\begin{array}{l}\text { Ex vivo residence time } \\
\text { (RT) }\end{array}$ & Patches Films Tablets & $\begin{array}{l}\text { Modified disintegration test } \\
\text { apparatus }\end{array}$ & disintegration tester & [96-98] \\
\hline
\end{tabular}

\section{Manufacturing methods of the buccal patches/films}

\section{Solvent casting}

This method is widely used for the manufacturing of the controlled release matrix and liquid reservoir type buccal film, oral disintegrating films, pellets and granules [35, 39].

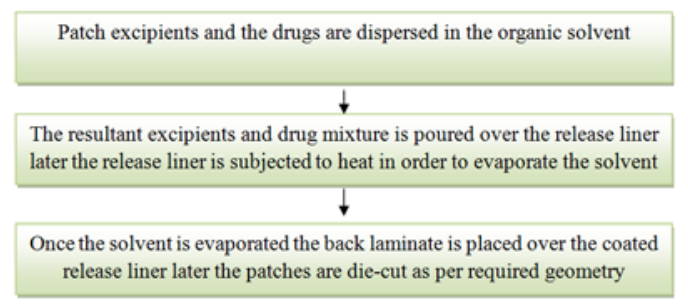

\section{Direct milling}

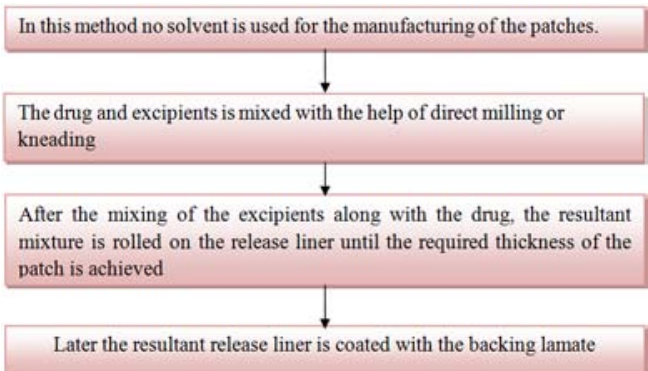

This method is widely used for the manufacturing of the oral buccal films and buccal wafers [54, 69].

\section{Hot melt extrusion of films}

This method is widely used for the manufacturing of the controlled release matrix tablets, oral disintegrating films, pellets and granules. The procedure of hot melts extrusion as follows [80, 97]:

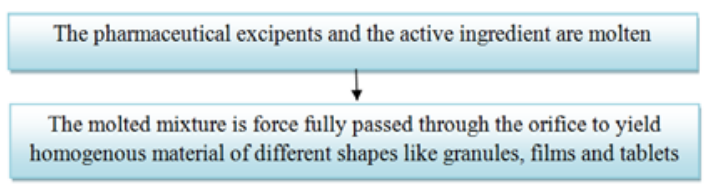

\section{Application of buccal drug delivery}

Table 6: Applications of BDDS

\begin{tabular}{ll}
\hline Applications & References \\
\hline$>$ Hypertension. Eg: Atenolol patches. & {$[86-102]$} \\
$>$ Hormone replacement therapy. & \\
$>$ Angina pectoris. Eg: Nitroglycerine patches. & \\
$>$ Cancer. Eg: Opiod analgesics. \\
$>$ Smoking cessation therapy. Eg: Nicotine \\
patches. \\
$>$ Treatment of microbial infections associated \\
with peridontitis. \\
$>$ Local therapy includes oral infections, moth \\
ulcers, dental caries, gingivitis, stomatitis.
\end{tabular}


Table 7: Patents of BDDS formulations

\begin{tabular}{|c|c|c|c|c|}
\hline S. No. & Title & Author & Patent number & Year \\
\hline 1. & $\begin{array}{l}\text { Buccal and/or sublingual therapeutic } \\
\text { formulation }\end{array}$ & $\begin{array}{l}\text { Cumming Alisthair, Kannar david, Sparrow } \\
\text { lance }\end{array}$ & AU2016238901A1 & 2016 \\
\hline 2. & $\begin{array}{l}\text { Bioadhesive films for oral and/or systemic } \\
\text { delivery }\end{array}$ & $\begin{array}{l}\text { Mcconville Jason Thomas, Morales Javier 0, } \\
\text { Ross Alistair }\end{array}$ & US2016128947A1 & 2016 \\
\hline 3. & Buccal delivery system & Rubina Mughal & GB2568554A & 2017 \\
\hline 4. & $\begin{array}{l}\text { Composition and method for Buccal } \\
\text { administration of GNRH agonists }\end{array}$ & De groot Aldemar B, Taneja Rajneesh & W02017208076A1 & 2017 \\
\hline 5. & $\begin{array}{l}\text { Sublingual or Buccal administration of DIM for } \\
\text { treatment of skin diseases }\end{array}$ & Scaife michael & W02018051183A1 & 2018 \\
\hline 6. & $\begin{array}{l}\text { Transmucosal delivery devices with enhanced } \\
\text { uptake }\end{array}$ & Finn Andrew, Vasisht Niraj & US2018133210A1 & 2018 \\
\hline 7. & $\begin{array}{l}\text { Chewable composition for rapid Buccal } \\
\text { absorption }\end{array}$ & Purcell Marc & US2019015324A1 & 2019 \\
\hline 8. & $\begin{array}{l}\text { Transdermal drug delivery systems for } \\
\text { levonorgestrel and ethinyl estradiol }\end{array}$ & Liao Jun, Nguyen Viet, Patel Prashant & US10231977B2 & 2019 \\
\hline 9. & Buccal swab delivery system & $\begin{array}{l}\text { Azimi Nooshin, Cauley Thomas H, Cohen } \\
\text { Bruce A, Schnipper Edward F }\end{array}$ & US2020376241A1 & 2020 \\
\hline 10. & $\begin{array}{l}\text { Device and methods for ultrasonic delivery of } \\
\text { an agent within an oral cavity }\end{array}$ & $\begin{array}{l}\text { France Marion, Schoellhammmer carl, } \\
\text { Sheppard Norman }\end{array}$ & W02020018866A1 & 2020 \\
\hline 11. & $\begin{array}{l}\text { Enhancing drug activity through accentuated } \\
\text { Buccal/sublingual administration }\end{array}$ & Banerjee Debasish, Banerjee Priyangbada & W02021019278A1 & 2021 \\
\hline
\end{tabular}

\section{Marketed products of bdds formulation}

Table 8: Marketed products of BDDS formulation

\begin{tabular}{|c|c|c|c|c|c|c|}
\hline S. No. & $\begin{array}{l}\text { Marketed } \\
\text { product }\end{array}$ & Active ingredient & Bioadhesive agent & Dosage form & Company/Manufacturer & $\begin{array}{l}\text { Therapeutic } \\
\text { class }\end{array}$ \\
\hline 1. & Buccastem $®$ & $\begin{array}{l}\text { Prochlorperazine } \\
\text { maleate }\end{array}$ & Xanthum gum & Buccal tablet & Reckitt Benckiser & Antipsychotics \\
\hline 2. & Corsodyl gel ${ }^{\circledR}$ & $\begin{array}{l}\text { Chlorhexidine } \\
\text { Digluconate }\end{array}$ & HPMC & Oral paste & GlaxoSmith Kline & Antimicrobial \\
\hline 3. & Actiq & Fentanyl citrate & Magnesium stearate & Lozenge & Cephalon & Opiod analgesics \\
\hline 4. & Suscard & Glyceryl trinitrate & Hypromellase & Tablet & Forest laboratories & Vasodilator \\
\hline 5. & Corlan pellets & $\begin{array}{l}\text { Hydrocortisone } \\
\text { sodium succinate }\end{array}$ & Acacia & $\begin{array}{l}\text { Oral mucosal } \\
\text { pellets }\end{array}$ & Celltech & Corticosteroids \\
\hline 6. & Fastum & Ketoprofen & PEG & Gel & A,Menarini industries & NSAIDS \\
\hline 7. & Coreg & Carvedilol & HPMC & Buccal patch & GlaxoSmith Kline & Hypertension \\
\hline 8. & Loramyc & Miconazole & Corn starch & Tablet & BioAliance pharma SA & Antifungal \\
\hline 9. & Bonjela $®$ & $\begin{array}{l}\text { Cetalkonium chloride, } \\
\text { Choline salicylate }\end{array}$ & Hypromellose & Gel & Reckitt Benckiser & Antiulcer \\
\hline 10. & Dentipatch® & Lidocaine & Xanthum gum & Patch & Noven & Analgesic \\
\hline
\end{tabular}

\section{Future outcomes}

Buccal drug delivery system offers advantages in accessibility, administration, economy, patient compliance. Novel preparations are focusing on the use of responsive polymeric system using copolymer with desirable hydrophilic/hydrophobic interaction, complexation networks, block or graft polymers from the natural edible sources. At the current global scenario, experts are finding ways to develop Buccal drug delivery with improved bioavailability of orally inefficient drugs by manipulating the formulation with enzyme inhibitors, inclusion of $\mathrm{pH}$, permeation enhancers. At present solid dosage forms, liquids, patches and gels are commercially successful.

\section{CONCLUSION}

The Buccal drug delivery system predominantly serves more advantages when compared to controlled drug delivery. It was a promising area for the systemic drug delivery of orally inefficient drugs. It has significant advantages like avoidance of presystemic elimination in GIT and first pass metabolism in liver. Buccal drug delivery can be affected by thickness of mucosal layer, barrier properties of mucosa, area of absorption site and it can be enhanced by penetration enhancers, bio-adhesive agents. In this review we have concluded that with the right dosage form design, mucoadhesive polymers and ideal formulation, the permeability and the local environment of mucosa can be controlled and manipulated in order to enhance drug permeation. This review will help pharmaceutical researchers to clarify the potential of BDDS to overcome the various existing drug delivery dispute like efficiency of absorption, permeability and bioavailability of drugs.

\section{FUNDING}

There was no specific funding for this case study from any source

\section{AUTHORS CONTRIBUTIONS}

Mrs. V. Leelalakshmi was involved in review of literature and collection of data and preparation of the manuscript. Mr. Umashankar MS, Mr Alagusundaram M was involved in reviewing, and editing of the manuscript.

\section{CONFLICT OF INTERESTS}

There is no conflict of interest for this review.

\section{REFERENCES}

1. DiMasi JA, Hansen RW, Grabowski HG. The price of innovation: new estimates of drug development costs. J Health Econ 2003;22(2):151-85. doi: 10.1016/S0167-6296(02)00126-1, PMID 12606142. 
2. Hearnden V, Sankar V, Hull K, Juras DV, Greenberg M, Kerr AR, Lockhart PB, Patton LL, Porter S, Thornhill MH. New developments and opportunities in oral mucosal drug delivery for local and systemic disease. Adv Drug Deliv Rev. 2012;64(1):16-28. doi: 10.1016/j.addr.2011.02.008, PMID 21371513.

3. Hoogstraate JAJ, Wertz PW, Wertz PW. Drug delivery via the buccal mucosa. Pharm Sci Technol Today. 1998;1(7):309-16. doi: 10.1016/S1461-5347(98)00076-5.

4. Mathias NR, Hussain MA. Non-invasive systemic drug delivery: develop ability considerations for alternate routes of administration. J Pharm Sci. 2010;99(1):1-20. doi: 10.1002/jps.21793, PMID 19499570.

5. Shojaei AH. Buccal Mucosa as a route for systemic drug delivery: a review. J Pharm Pharm Sci. 1998;1(1):15-30. PMID 10942969.

6. Lis Fontinele de Sa L, Nogueira NC, Da Silva Filho EC, Figueiras A, Veiga F, Nunes LCC, Lamartine Soares-Sobrinho J. Design of buccal mucoadhesive tablets: understanding and development. J Appl Pharm Sci. 2018;8:150-63.

7. Venkataswamy R, Lavanya Nallaguntla. Review article on pulsatile drug delivery system. Asian J Pharm Clin Res. 2021;14:48-59.

8. Carvalho FC, Bruschi ML, Evangelista RC, Gremião MPD. Mucoadhesive drug delivery systems. Braz J Pharm Sci. 2010;46(1):1-17. doi: 10.1590/S1984-82502010000100002.

9. Satishbabu BK, Srinivasan BP. Preparation and evaluation of buccoadhesive films of atenolol. Indian J Pharm Sci. 2008;70(2):175-9. doi: 10.4103/0250-474X.41451, PMID 20046708.

10. Palem CR, Gannu R, Yamsani SK, Yamsani VV, Yamsani MR. Development of bioadhesive buccal tablets for felodipine and pioglitazone in combined dosage form: in vitro, ex vivo, and in vivo characterization. Drug Deliv. 2011;18(5):344-52. doi: 10.3109/10717544.2011.557786, PMID 21351826.

11. Chinna Reddy PKS, Chaitanya KS, Madhusudan Rao Y. A review on bioadhesive Buccal drug delivery systems: current status of formulation and evaluation methods. Daru. 2011;19(6):385403. PMID 23008684.

12. Harris D, Robinson JR. Drug delivery via the mucous membranes of the oral cavity. J Pharm Sci. 1992;81(1):1-10. doi: 10.1002/jps.2600810102, PMID 1619560.

13. Wertz PW, Squier CA. Cellular and molecular basis of barrier function in oral epithelium. Crit Rev Ther Drug Carrier Syst. 1991;8(3):237-69. PMID 1954652.

14. Thakur G, Wani SUD, Gautam SP. A review on recent advancement in pulsatile drug delivery systems. Int J Curr Pharm Res. 2021;13:6-10.

15. Kamimori GH, Karyekar CS, Otterstetter R, Cox DS, Balkin TJ, Belenky GL, Eddington ND. The rate of absorption and relative bioavailability of caffeine administered in chewing gum versus capsules to normal healthy volunteers. Int $\mathrm{J}$ Pharm. 2002;234(1-2):159-67. doi: 10.1016/s0378-5173(01)00958-9, PMID 11839447.

16. Zhang J, Streisand J, Niu S. Estimation of bucccal fentanyl absorption bioavailability by measuring drug depletion from vehicle solutions: validation of the method in dogs. Pharm Res. 1992;9:S177.

17. Chinna Reddy P, Madhusudan Rao Y. Buccal drug delivery systems. Adv Drug Deliv Rev. 2010;1:139-210.

18. Patel KV, Patel ND, Dodiya HD, Shelat PK. Buccal bioadhesive drug delivery system: an overview. Int J Pharm Bio Arch. 2011;2:600-9.

19. Patel VM, Prajapati BG. Design and in vitro characterization of eudragit containing mucoadhesive buccal patches. Int J Pharm Tech Res. 2009;1:783-9.

20. Gandhi Pankil A. A review article on muco-adhesive Buccal drug delivery system. IJPRD. 2011;3:159-73.

21. Wise Donald L. Handbook of Pharmaceutical controlled release technology; 2000. p. 255-65.

22. Khairnar GA, Sayyad FJ. Development of Buccal drug delivery system based on mucoadhesive polymer. Int J PharmTech Res. 2010;2:719-35.

23. Utoguchi N, Watanabe $\mathrm{Y}$, Suzuki T, Maehara J, Matsumoto Y, Matsumoto M. Carrier-mediated transport of monocarboxylic acids in primary cultured epithelial cells from rabbit oral mucosa. Pharm Res. 1997;14(3):320-4. doi: 10.1023/a:1012046021028. PMID 9098874.

24. Shinde AKJ, Patil NS, Jadhav TS, More HN. Design and development of floating pulsatile drug delivery of losartan potassium. Int J Appl Pharm. 2020;12:218-27.

25. Vyas SP, Khar RK. Controlled drug delivery-concepts and advances. Vallabh Prakashan. 1st ed. New Delhi; 2002.

26. Bottenberg P, Cleymaet R, de Muynck C, Remon JP, Coomans D, Michotte Y, Slop D. Development and testing of bioadhesive, fluoride-containing slow-release tablets for oral use. J Pharm Pharmacol. 1991;43(7):457-64. doi: 10.1111/j.20427158.1991.tb03514.x, PMID 1682457.

27. Rossi S, Sandri G, Caramella CM. Buccal drug delivery: A challenge already won? Drug Discov Today Technol. 2005;2(1):59-65. doi: 10.1016/j.ddtec.2005.05.018, PMID 24981756.

28. Junginger HE, Hoogstraate JA, Verhoef JC. Recent advances in buccal drug delivery and absorption- in vitro and in vivo studies. J Control Release. 1999;62(1-2):149-59. doi: 10.1016/s0168-3659(99)00032-2, PMID 10518646.

29. Salamat-Miller NS, Chittchang M, Johnston TP. The use of mucoadhesive polymers in buccal drug delivery. Adv Drug Deliv Rev. 2005;57(11):1666-91. doi: 10.1016/j.addr.2005.07.003, PMID 16183164.

30. Wani Manish S. Current status in buccal drug delivery system. Pharmainfo Net. 2007;5:1-15.

31. Kumar. Mechanism of Buccal permeation enhancers. Indian J Pharm Edu. 2002;36:147-51.

32. Trastullo R, Abruzzo A, Saladini B, Gallucci MC, Cerchiara T, Luppi B, Bigucci F. Design and evaluation of buccal films as paediatric dosage form for transmucosal delivery of ondansetron. Eur J Pharm Biopharm. 2016;105:115-21. doi: 10.1016/j.ejpb.2016.05.026, PMID 27267732.

33. Alur HH, Johnston TP, Mitra AK. Encyclopedia of pharmaceutical technology. In: Swarbrick J, Boylan JC, editors, Peptides and protein S: buccal absorption. Vol. 20. New York: Marcel Dekker Inc; 2001. p. 193-218.

34. Hao J, Heng PW. Buccal delivery systems. Drug Dev Ind Pharm. 2003;29(8):821-32. doi: 10.1081/ddc-120024178, PMID 14570303.

35. kaur A, kaur G. Mucoadhesive buccal patches based on interpolymer complexes of chitosan-pectin for delivery of carvedilol. Saudi Pharm J. 2012;20(1):21-7. doi: 10.1016/j.jsps.2011.04.005, PMID 23960773.

36. Veuillez F, Kalia YN, Jacques Y, Deshusses J, Buri P. Factors and strategies for improving Buccal absorption of peptides. Eur J Pharm Biopharm. 2001;51(2):93-109. doi: 10.1016/s09396411(00)00144-2, PMID 11226816.

37. Barocas VH, Balachandran RK. Sustained transscleral drug delivery. Expert Opin Drug Deliv. 2008;5(1):1-10. doi: 10.1517/17425247.5.1.1. PMID 18095925.

38. Verma S, Kaul M, Rawat A, Saini S. An overview on Buccal drug delivery system. IJSR. 2011;2:1303-21.

39. Himabindu. Formulation and in vitro evaluation of mucoadhesive buccal patches of cyproheptadine hydrochloride. J App Pharm Sci. 2012;2:196-201. doi: 10.7324/JAPS.2012.2731.

40. Wong CF, Yuen KH, Peh KK. An in vitro method for buccal adhesion studies: importance of instrument variables. Int J Pharm. 1999;180(1):47-57. doi: 10.1016/s03785173(98)00402-5, PMID 10089291.

41. Reddy RJ, Anjum M, Hussain MA. A comprehensive review on buccal drug delivery system. AJADD. 2013;1:300-12.

42. semalty $M$, Semalty A, Kumar G. Formulation and characterization of mucoadhesive buccal films of glipizide. Indian J Pharm Sci. 2008;70(1):43-8. doi: 10.4103/0250474X.40330, PMID 20390079.

43. Vani C, Srinivas Reddy K. Pulsatile drug delivery system-a technique of delivering drug in accordance with biological clock- a review. Int J Adv Res. 2021;9(4):101-24. doi: 10.21474/IJAR01/12813.

44. Aungst BJ, Rogers NJ. Site dependence of absorption-promoting actions of laureth-9, Na salicylate, Na2EDTA, and aprotinin on rectal, nasal, and buccal insulin delivery. Pharm Res. 1988;5(5):305-8. doi: 10.1023/a:1015930821648, PMID 2469079. 
45. Fariya Mozammel F, Irin Dewan SM, Ashraful Islam Ashraful. A comprehensive review on Buccal drug delivery system. World J Pharm Pharm Sci. 2019;8:77-93.

46. Dibyalochan Mohanty, Gurulatha GC, Vasudha Bakshi V, Mavya B. Novel approaches on buccal mucoadhesive drug delivery system. Indo Am J Pharmacol Sci. 2018;5:2131-45.

47. Wadageri GV, Raju SA, Shirsand SB, Reddy VP. Buccal drug delivery system of atenolol. Res J Pharm Technol. 2012;5:1-18.

48. Boateng JS, Areago D. Composite sodium alginate and chitosan based wafers for Buccal delivery on macromolecules. Austin J Anal Pharm Chem. 2014;1:16-24.

49. Raghavendra Rao NG, Shravani B, Mettu Srikanth Reddy M. Overview on buccal drug delivery systems. J Pharm Sci. 2013;5:80-8.

50. Dhanashri Garud P, Kalyani Dalavi K, Sagar Doele. Application of thiolated chitosan in mucoadhesive Buccal drug delivery system. Application of thiolated chitosan in mucoadhesive Buccal drug delivery system. World J Pharm Res. 2020;9:622-36.

51. Gite Shital Shridhar, Shinkar Dattataraya Manohar, Saudagar Ravindra Bhanudas. Mucoadhesive Buccal drug delivery: an overview. Japer. 2013;3:319-32.

52. Patel D, Patel C, Shah P. Formulation and evaluation of bioadhesive Buccal drug delivery of repaglinide tablets. Asian J Pharm. 2012;6(3):171-9. doi: 10.4103/0973-8398.104830.

53. Reddy Jagadeeshwar R Maimuna Anjum, Mohammed Asif Hussain. A comprehensive review on Buccal drug delivery system. Am J Adv Drug Deliv. 2013;1:300-12.

54. Seema, Kapil Kumar, Deepak Teotia. A comprehensive review on buccal patches. GSC Biol Pharm Sci;13(1):130-5. doi: 10.30574/gscbps.2020.13.1.0308.

55. Ghate SK, Sakarkar. DM. Development and evaluation of osmotically controlled oral drug delivery system. Asian J Pharm Technol. 2017;7(4):459-70. doi: 10.5958/22315713.2017.00033.2.

56. Yamagar M, Kadam V, Hirlekar R. Design and evaluation of buccoadhesive drug delivery system of metoprolol tartarate. Int J Pharm Tech Res. 2010;2:453-62.

57. Mohammadi Samani Soliman, Bahri Najafi Rahim, Yousefi Golamhosein. Formulation and in vitro evaluation of prednisolone buccoadhesive tablets. Farmaco. 2005;60(4):33944. doi: 10.1016/j.farmac.2005.01.009, PMID 15848210.

58. Rajaram Dipak Malpure, Laxman Sharada Deore. Buccal mucoadhesive films: a review. Syst Rev Pharm. 2016;8(1):31-8. doi: 10.5530/srp.2017.1.7.

59. Reddy Sunitha M, Surekha, Anusha G, Mallikarjun Reddy S, Manasa K, Soumya G. A review on transbuccal drug delivery system and its commercially available products. Res J Pharm Technol. 2013;6:1-16.

60. Chaudhari SR, Harsulkar AA. Design and in vitro evaluation of mucoadhesive buccal tablets of carvedilol. Int J Pharm Tech Res. 2012;4:1827-33.

61. Singh R, Sharma D, Garg R. Review on mucoadhesive drug delivery sysem with special emphasis on Buccal route: An important tool in designing of novel controlled drug delivery system for the effective delivery of pharmaceuticals. J Dev Drugs. 2017;6:1-12.

62. El-Maghraby Gamal M, Abdelzaher Mona M. Formulation and evaluation of simvastatin Buccal film. J App Pharm Sci. 2015;5:70-7. doi: 10.7324/JAPS.2015.50412.

63. Chin Nala Krishna Mohan, Panigrahy Rabi Narayan, Mesa Rajendra, Deshu Isaac. Formulation and in vitro evaluation of bilayer muco adhesive drug delivery system containing nifedipine. Int J Pharm Educ. 2014;1:1-8.

64. Patel KV, Patel ND, Dodiy HD, Shelat PK. Buccal bioadhesive drug delivery system: an overview. Int J Pharm Biol Sci Arch. 2011;2:600-9.

65. Pranshu Tangri Satheessh Madhav NV. Oral mucoadhesive drug delivery systems: a review. Int J Biopharm. 2011;2:36-46.

66. Roychowdhury Santanu, Guptha Rajesh, Saha Sourav. A review on Buccal mucoadhesive drug delivery systems. Indo Glob J Pharm Sci. 2011;1:223-33.

67. AL-Dhubiab Bandar E, Nair Anroop B, Kumria Rachna, Attimarad Mahesh, harsha Sree. Formulation and evaluation of nanobased drug delivery system for the Buccal delivery of acyclovir. Colloids Surf B Biointerfaces. 2015;136:878-84. doi: 10.1016/j.colsurfb.2015.10.045, PMID: 26547315

68. Wang Y, Lian Z, Chen M, Zhang L, Zhou C, Wei W. Bioadhesive drug delivery system of diltiazem hydrochloride for improved bioavailability in cardiac therapy. Trop J Pharm Res. 2016;15(7):1375-80. doi: 10.4314/tjpr.v15i7.4.

69. Vishnu Y Vamshi, Chandrasekhar K, Ramesh G, Rao Y Madhusudan. Development of mucoadhesive patches for buccal administration of carvedilol. Curr Drug Deliv. 2007;4(1):27-39. doi: 10.2174/156720107779314785, PMID 17269915.

70. Patil SB, Murthy RSR, Mahajan HS, Wagh RD, Gattani SG. Mucoadhesive polymers: means of improving drug delivery. J Pharm Times. 2006;38:25-8.

71. Singh Chhotec Lal, Srivastava Namita, Monga Munish Garg, Singh Amit. A review: buccal buccoadhesive drug delivery system. World J Pharm Res. 2014;2:1803-7.

72. Bhanja SB, Ellaiah P, Martha SK, Kar RK, Panigrahi BB. Buccoadhesive drug delivery system of captopril: formulation and in vitro evaluation. J Pharm Res. 2010;3:335-40.

73. Parodi B, Russo E, Caviglioli G, Cafaggi S, Bignardi G. Development and characterization of a buccoadhesive dosage form of oxycodone hydrochloride. Drug Dev Ind Pharm. 1996;22(5):445-50. doi: 10.3109/03639049609069353.

74. Raju KN, Velmurugan S, Deepika B, Sundar V. Formulation and in vitro Evaluation of buccal tablets of metoprolol tartrate. Int J Pharm Pharm Sci. 2011;3:239-46.

75. Yamagar M, Kadam V, Hirlekar R. Design and evaluation of buccoadhesive drug delivery system of metoprolol tartrate. Int J Pharm Tech Res. 2010;2:453-62.

76. Yamsani Vamshi Vishnu, Gannu Ramesh, Kolli Chandrasekhar, Rao ME Bhanoji EB, Yamsani Madhusudan Rao. Development and in vitro evaluation of buccoadhesive carvedilol tablets. Acta Pharm. 2007;57(2):185-97. doi: 10.2478/v10007-007-0015-7, PMID 17507315.

77. Shinde Anil Kumar J, Patil Nidhi S, Jadhav Trupti S, More Harinath N. Design and development of floating pulsatile drug delivery of losartan potassium. Int J App Pharm. 2020;12:21827. doi: 10.22159/ijap.2020v12i4.37607.

78. Nafee Noha Adel, Ismail Fatma Ahmed, Boraie Nabila Ahmed, Mortada Lobna Mohamed. Mucoadhesive delivery systems. I. Evaluation of mucoadhesive polymers for buccal tablet formulation. Drug Dev Ind Pharm. 2004;30(9):985-93. doi: 10.1081/ddc-200037245. PMID 15554223.

79. Jain NK. Controlled and novel drug delivery. 1st ed. New Delhi: CBS Publishers; 2004. p. 236-55.

80. Singh TP, Singh RK, Shah JN, Mehta TA. Mucoadhesive bilayer buccal patches of verapamil hydrochloride: formulation development and characterization. Int J Pharm Pharm Sci. 2014;6:234-41.

81. Prasanth VV, Sirisha M, Mathew Sam T, Mathapan Rinku. Buccal tablet as mucoadhesive drug delivery: an over view. J Pharm Res. 2011;4:706-9.

82. Borgaonkar PA, Virsen TG, Hariprasanna RC, Najmuddin M. Formulation and in vitro evaluation of buccal tablets of loratadine for effective treatment of allergy. Int J Res Pharm Chem. 2011;1:551-9.

83. Naga Raju K, Velmurugan S, Deepika B, Vinushitha Sundar. Formulation and in vitro evaluation of buccal tablets of metoprolol tartrate. Int J Pharm Pharm Sci. 2011;13:239-46.

84. Senel Sevda, Hincal AA. Drug permeation enhancement via buccal route: possibilities and limitations. J Control Release. 2001;72(1-3):133-44. doi: 10.1016/s0168-3659(01)00269-3, PMID 11389992.

85. Shojaei AH. Buccal mucosa as a route for systemic drug delivery: a review. J Pharm Pharm Sci. 1998;1(1):15-30. PMID 10942969.

86. Kadam Prasad B, Dias Remeth J, Mali Kailas K, Havaldar Vijay D, Mahajan Niranjan S. Formulation and evaluation of buccoadhesive tablets of atenolol. J Pharm Res. 2008;1:193-9.

87. Satishbabu BK, Srinivasan BP. Preparation and evaluation of buccoadhesive films of atenolol. Indian J Pharm Sci. 2008;70(2):175-9. doi: 10.4103/0250-474X.41451, PMID 20046708.

88. Mohammed Fergany A, Khedr Hussin. Preparation and in vitro/in vivo evaluation of the buccal bioadhesive properties of 
slow-release tablets containing miconazole nitrate. Drug Dev Ind Pharm. 2003;29(3):321-37. doi: 10.1081/ddc-120018206, PMID 12741613.

89. Tiwari D, Sause R, Madan PL, Goldman D. Evaluation of polyoxyethylene homopolymers for buccal bioadhesive drug delivery device formulations. AAPS PharmSci. 1999;1(3):50-7. doi: 10.1208/ps010313.

90. Sharmin N, Elias-Al-Mamun M, Islam MS, Jalil R. Preparation and characterization of lidocaine double layer buccal tablet using mucoadhesive carbopol@ polymers. Dhaka Univ J Pharm Sci. 2011;10(1):29-34. doi: 10.3329/dujps.v10i1.10012.

91. Desai KG, Kumar TM. Preparation and evaluation of a novel buccal adhesive system. AAPS PharmSciTech. 2004;5(3):e35. doi: 10.1208/pt050335, PMID 15760069.

92. Abd-Elbary A, Makky AMA, Tadros MI, AA Alaa-eldin. Development and in vitro evaluation of mucoadhesive bilayer buccal tablets of carvedilol. Int J Pharm Pharm Sci. 2015;7:172-6.

93. Darekar SS, Khadabadi SS, Shahi SR. Formulation and evaluation of bilayer buccal tablet of sumatriptan succinate. Int J Pharm Pharm Sci. 2014;6:469-75.

94. Abouhussein DMN, El-bary AA, Shalaby SH, Nabarawi MAE. Chitosan mucoadhesive buccal films: effect of different casting solvents on their physicochemical properties. Int J Pharm Pharm Sci. 2016;8(9):206-13. doi: 10.22159/ ijpps.2016.v8i9.12999.

95. Mumtaz AM, Ch'ng HS. Design of a dissolution apparatus suitable for in situ release study of triamcinolone acetonide from bioadhesive buccal tablets. Int J Pharm. 1995;121(2):12939. doi: 10.1016/0378-5173(94)00406-U.

96. Peddapalli H, Chinnala KM, Banala N. Design and in vitro characterization of mucoadhesive buccal patches of duloxetine hydrochloride. Int J Pharm Pharm Sci. 2017;9(2):52-9. doi: 10.22159/ijpps.2017v9i2.13793.

97. Peh KK, Wong CF. Polymeric films as vehicle for buccal delivery: swelling, mechanical, and bioadhesive properties. J Pharm Pharm Sci. 1999;2(2):53-61. PMID 10952770.

98. Singh B, Chakkal SK, Ahuja N. Formulation and optimization of controlled release mucoadhesive tablets of atenolol using response surface methodology. JAAPS Pharm. Sci Technol. 2006;7:1.

99. Hoogstraate JAJ, Wertz PW, Wertz PW. Drug delivery via the buccal mucosa. Pharm Sci Technol Today. 1998;1(7):309-16. doi: 10.1016/S1461-5347(98)00076-5.

100. Han RY, Fang JY, Sung KC, Hu OYP. Mucoadhesive buccal disks for novel nalbuphine prodrug controlled delivery: effect of formulation variables on drug release and mucoadhesive performance. Int J Pharm. 1999;177(2):201-9. doi: 10.1016/s0378-5173(98)00343-3, PMID 10205614.

101. Deasy PB, O’Neill CT. Bioadhesive dosage form for peroral administration of timolol base. Pharm Acta Helv. 1989;64(8):231-5. PMID 2780757.

102. Agaiah Goud B, Kumara Swamy S, Praveen Kumar V. Formulation and evaluation of bioadhesive buccal tablets of simvastatin. Adv Pharmacol Sci. 2011;1:29-38. 